\title{
Biodegradation of Crystal Violet dyes by bacteria isolated from textile industry effluents
}

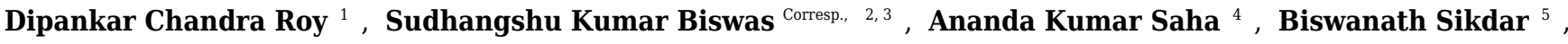 \\ Mizanur Rahman ${ }^{3}$, Apurba Kumar Roy ${ }^{5}$, Zakaria Hossain Prodhan ${ }^{2,6}$ ， Swee-Seong Tang ${ }^{2}$ \\ 1 Biomedical and Toxicological Research Institute, Bangladesh Council of Scientific and Industrial Research, Dhaka, Bangladesh \\ 2 Division of Microbiology, Institute of Biological Sciences, Faculty of Science, University of Malaya, Kuala Lampur, Malaysia \\ 3 Department of Biotechnology and Genetic Engineering, Faculty of Applied Science and Technology, Islamic University Kushtia, Kushtia, Bangladesh \\ 4 Department of Zoology, Faculty of Life and Earth Sciences, University of Rajshahi, Rajshahi, Bangladesh \\ 5 Department of Genetic Engineering and Biotechnology, Faculty of Life and Earth Sciences, University of Rajshahi, Rajshahi, Bangladesh \\ 6 Institute of Crop Science, College of Agriculture and Biotechnology, Zhejiang University, Hangzhou, China \\ Corresponding Author: Sudhangshu Kumar Biswas \\ Email address: shu_genetics@yahoo.com
}

Industrial effluent containing textile dyes is regarded as a major environmental concern in the present world. Crystal Violet is one of the vital textile dyes of triphenylmethane group, widely used in textile industry, known for its mutagenic and mitotic poisoning nature. Bioremediation, especially through bacteria is becoming an emerging and important sector in effluent treatment. This study aimed to isolate and identify Crystal Violet degrading bacteria from industrial effluents with potential use in bioremediation. The decolorizing activity of the bacteria was measured using photo electric colorimeter after aerobic incubation in different time intervals of the isolates. Environmental parameters such as $\mathrm{pH}$, temperature, initial dye concentration and inoculum size were optimized using mineral salt medium containing different concentration of Crystal Violet dye. Complete decolorizing efficiency was observed in mineral salt medium containing up to $150 \mathrm{mg} / \mathrm{l}$ of Crystal Violet dye by $10 \%(\mathrm{v} / \mathrm{v}$ ) inoculums of Enterobacter sp. CV-S1 tested under 72 hours of shaking incubation at temperature $35^{\circ} \mathrm{C}$ and $\mathrm{pH}$ 6.5. Newly identified bacteria Enterobacter sp. CV-S1 confirmed by $16 \mathrm{~S}$ ribosomal RNA sequencing, was found as a potential bioremediation biocatalyst in the aerobic degradation/de-colorization of Crystal Violet dye. The efficiency of degrading triphenylmethane dye by this isolate, minus the supply of extra carbon or nitrogen sources in the media highlights the significance of larger-scale treatment of textile effluent. 
1 Biodegradation of Crystal Violet dyes by bacteria isolated from textile industry effluents

\section{Dipankar Chandra Roy ${ }^{1}$, Sudhangshu Kumar Biswas ${ }^{23 *}$, Ananda Kumar Saha ${ }^{4}$,}

4 Biswanath Sikdar ${ }^{5}$, Mizanur Rahman ${ }^{3}$, Apurba Kumar Roy ${ }^{5}$, Zakaria Hossain Prodhan ${ }^{2}$

$7 \quad{ }^{1}$ Biomedical and Toxicological Research Institute, Bangladesh Council of Scientific and

8 Industrial Research, Dhaka, Bangladesh.

$9{ }^{2}$ Division of Microbiology, Institute of Biological Sciences, Faculty of Science, University of

10 Malaya, Kuala Lumpur, Malaysia.

$11{ }^{3}$ Department of Biotechnology and Genetic Engineering, Faculty of Applied Science and

12 Technology, Islamic University, Kushtia, Bangladesh.

$13{ }^{4}$ Department of Zoology, Faculty of Life and Earth Sciences, University of Rajshahi, Rajshahi, 14 Bangladesh.

$15{ }^{5}$ Department of Genetic Engineering and Biotechnology, Faculty of Life and Earth Sciences, 16 University of Rajshahi, Rajshahi, Bangladesh.

$17{ }^{6}$ Institute of Crop Science, College of Agriculture and Biotechnology, Zhejiang University, 18 Hangzhou, China. 


\section{Abstract}

33 Industrial effluent containing textile dyes is regarded as a major environmental concern in the 34 present world. Crystal Violet is one of the vital textile dyes of triphenylmethane group, widely 35 used in textile industry, known for its mutagenic and mitotic poisoning nature. Bioremediation, 36 especially through bacteria is becoming an emerging and important sector in effluent treatment. 37 This study aimed to isolate and identify Crystal Violet degrading bacteria from industrial 38 effluents with potential use in bioremediation. The decolorizing activity of the bacteria was measured using photo electric colorimeter after aerobic incubation in different time intervals of

40 the isolates. Environmental parameters such as $\mathrm{pH}$, temperature, initial dye concentration and 41 inoculum size were optimized using mineral salt medium containing different concentration of 42 Crystal Violet dye. Complete decolorizing efficiency was observed in mineral salt medium 43 containing up to $150 \mathrm{mg} / \mathrm{l}$ of Crystal Violet dye by $10 \%(\mathrm{v} / \mathrm{v})$ inoculums of Enterobacter sp. CV$44 \mathrm{~S} 1$ tested under 72 hours of shaking incubation at temperature $35^{\circ} \mathrm{C}$ and $\mathrm{pH} 6.5$. Newly identified 45 bacteria Enterobacter sp. CV-S1 confirmed by $16 \mathrm{~S}$ ribosomal RNA sequencing, was found as a 46 potential bioremediation biocatalyst in the aerobic degradation/de-colorization of Crystal Violet 47 dye. The efficiency of degrading triphenylmethane dye by this isolate, minus the supply of extra 48 carbon or nitrogen sources in the media highlights the significance of larger-scale treatment of 49 textile effluent. 


\section{1. Introduction}

66 The textile industry plays a vital role in the global economy as well as in our daily life,

67 concurrently turn into one the main source of environmental pollution in the world in terms of 68 quality and quantity (Mondal et al. 2017). The textile industry consumes a larger volume of water 69 in which almost ninety percent appears as wastewater (Verma et al. 2012). Textile wastewater 70 contains the different type of dyes as the major pollutant which is not only recalcitrant but also 71 imparts intense color to the waste effluent (Mondal et al. 2017). Inappropriate disposal of textile 72 wastewater causes serious environmental problems that affect the aquatic organism adversely 73 (Subhathra et al. 2013; Mondal et al. 2017). Improper effluent disposal in aqueous ecosystems 74 leads to reduction of sunlight penetration which in turn diminishes photosynthetic activity, 75 resulting in acute toxic effects on the aquatic flora/fauna and dissolved oxygen concentration 76 (Muhd Julkapli et al. 2014).

78 The wastewater produced from the textile, dye and dyestuff industries is a complex combination 79 of various inorganic and organic materials (Fulekar et al.2013). Dyes commonly have a synthetic 80 origin and complex aromatic molecular structures which make them more stable and more 81 difficult to biodegrade. The textile industries consume the largest amount of dyestuffs, at nearly 82 60-70\% (Bhattacharya et al. 2018; Mudhoo \& Beekaroo 2011; Rawat et al. 2016) which play a 83 vital role to prepare raw materials to pretreatment materials together with dyeing and finishing of 84 textile materials (Jana et al. 2015; Sriram et al. 2013). Due to the wide range of dyes, fibers, 85 process auxiliaries and final products during the dyeing processes, ample amount ( about 10$8690 \%$ ) of dye-stuffs that do not bind to the fibers were released into the sewage treatment system 87 or the environmental water (Abadulla et al. 2000; Zollinger 2003). Dye wastes represent one of 88 the most awkward groups of pollutants because they easily may recognize by naked eyes and are 89 non-biodegradable (Mojsov et al. 2016).

91 Triphenylmethane dyes are synthetic compounds widely used in various industries and their 92 removal from effluents are tough, due to their higher degree of structural complexity (Morales93 Álvarez et al. 2017). The presence of complex mixture in textile effluent directly indicates the 94 water has been polluted, and this highly colored effluent is forthrightly responsible for polluting 95 the receiving water (Rajamohan \& Rajasimman 2012). 
96 As a result, inappropriate textile dye effluent disposal in aqueous ecosystems leads adverse

97 impact on chemical oxygen demand (COD) and high biological oxygen demand (BOD). Their

98 metabolites lead to toxic, carcinogenic and mutagenic effect to flora and fauna which eventually

99 cause severe environmental problems worldwide (Mittal et al. 2005; Sharma et al. 2009).

100

101 Due to their toxic, mutagenic and carcinogenic properties as well as their contribution to the de102 coloration of natural waters, the release of dyes and their metabolites into the environment is a 103 source of concern (Khadijah et al. 2009). Thus, precise attention should be taken into 104 consideration on the utilization of dyes industrially. Inadequate method has been reported yet to 105 decolorize textile effluents economically. For the removal of synthetic dyes from the water 106 bodies, a number of physicochemical methods, such as filtration, specific coagulation, use of 107 activated carbon and chemical flocculation, have been used (Olukanni et al. 2006; Verma et al. 108 2012). Using these expensive physiochemical methods, vast amounts of sludge is produced, 109 which resulted into the secondary level of land pollution (Shah 2013). For this reason, there is 110 urgent need for economically inexpensive and eco-friendly removal techniques of the polluting 111 dyes. As a potential alternative, the biological process including several taxonomic groups of 112 microbes such as bacteria, fungi, yeast together with algae have been recognized growing interest 113 due to their cost-effectiveness, less sludge producing ability, and eco-friendly (Kalyani et al. 114 2009). Bacteria from different trophic groups can achieve a higher degree of dye-degradation and 115 can process a complete mineralization of dyes under optimal conditions (Asad et al. 2007). 116 Recently, microbial degradation of textile effluent has been reported as an economical and eco117 friendly than physiochemical methods (Shah 2013).

118 The present study aimed to isolate and characterize Crystal Violet degrading bacteria from textile 119 industry effluents for potential use in industrial bioremediation process.

\section{2. Materials and methods}

\section{2.1. Sample collection}

123 The untreated water and sludge samples of textile effluent were collected from two local thread 124 dyeing plants namely Rana Textile and Bulbul Textile Industries Ltd from Kumarkhali, Kushtia, 125 Bangladesh. Four samples, named as water-1, water-2, sludge-1 and sludge-2, were collected 126 from stagnant textile effluents from drainage canal. The color, $\mathrm{pH}$ and temperature of the samples 
127 were measured and recorded. The samples were collected in sterile plastic bottles, brought to the

128 laboratory and kept at $4^{\circ} \mathrm{C}$ in refrigerator for preservation within 24 hours of sampling.

129 2.2. Bacterial isolation

130 All four samples (untreated textile effluents) were used to isolate dye decolorizing bacteria by

131 modified enrichment culture techniques as stated by Shah (2013). Steps involved enrichment,

132 isolation and screening of dye decolorizing bacteria were (i) $1 \mathrm{ml}$ of each sample was first diluted

133 with $9 \mathrm{ml}$ of sterilized water and the stock was kept in static condition for few minutes for

134 precipitation (ii) $1 \mathrm{ml}$ supernatant from each diluted sample was transferred into $9 \mathrm{ml}$ enrichment

135 medium and a required amount of crystal violet dye solution was added into the stock to adjust

136 the concentration (iii) The species showing remarkable decolorization within 24 to 72 hours

137 were streaked on $2 \%$ enrichment agar medium containing $100 \mathrm{mg} / 1$ of crystal violet dye (iv)

138 Colonies of bacteria those exhibited a clear decolorization zone around them on enrichment agar 139 medium were picked and cultured (v) An individual colony was then reintroduced into $9 \mathrm{ml}$ 140 enrichment medium containing Crystal Violet dye and was incubated overnight. (vi) $10 \%$ of 141 overnight cultured isolates were inoculated into $10 \mathrm{ml} \mathrm{MS}$ medium supplemented with $1 \mathrm{ml} / 1 \mathrm{TE}$ 142 solution and $100 \mathrm{mg} / \mathrm{l}$ crystal violet dye and incubated overnight. (vii) $2 \mathrm{ml}$ of the sample was 143 then removed aseptically and centrifuged for 10 minutes at 10,000 rpm. (viii) This supernatant 144 was used to determine the decolorization percentage of the added dye. (ix) Isolates exhibited 145 most decolorizing efficiency were selected and preserved (in nutrient agar up to 1 month and in $14650 \%$ glycerol up to 6 months) for further studies.

148 2.3. Bacterial growth determination

149 In order to determine the effect of $\mathrm{pH}$ on bacterial growth, the isolated bacteria CV-S1 was 150 cultured in nutrient broth. A twenty four hours observation was done at $35^{\circ} \mathrm{C}$ temperate using 10 $151 \mathrm{ml}$ MS medium containing 10\% (v/v) inoculums and $50 \mathrm{mg} / \mathrm{l}$ Crystal Violet dye of varying $\mathrm{pH}$ $152(6.00,6.50,7.00,7.50,8.00$ and 8.50). To determine the optimum temperature, degradation assay 153 was performed from 30 to $40^{\circ} \mathrm{C}$ temperature using same stock condition at pH 6.50 (Shah et al. 1542013 ; Prasad et al. 2013). 
157 The genomic DNA extraction was performed using modified CTAB method as described by

158 Winnepenninckx et al. (Winnepenninckx et al. 1993) and the quality of DNA was analyzed

159 through Gel electrophoresis in 1\% agarose gel.

160

161 2.5. 16S ribosomal RNA sequencing for bacterial identification

162 Partial sequence of $16 \mathrm{~S}$ ribosomal RNA was carried by using Applied Biosystem 3130. The

163 bacteria-specific forward primer F27 (AGAGTTTGATCCTGGCTCAG) and reverse primer

164 R1391 (GACGGGCGGTGTGTRCA) were used to amplify DNA fragments in PCR. The recipe

165 of a total of $25 \mu \mathrm{l}$ of reaction mixture was $\mathrm{ddH}_{2} \mathrm{O} 14.75 \mu 1, \mathrm{MgCl}_{2}(25 \mathrm{mM}) 2 \mu \mathrm{l}$, buffer (10×) 2.5

$166 \mu 1$, dNTPs $(10 \mathrm{mM}) 0.5 \mu 1$, Taq DNA Polymerase $(5 \mathrm{u} / \mu 1) 0.25 \mu 1$, DNA template $1 \mu 1$, forward

167 primer $(10 \mu \mathrm{M}) 2 \mu 1$ and reverse primer $(10 \mu \mathrm{M}) 2 \mu 1$. The PCR amplification was performed by

168 Swift $^{\mathrm{TM}}$ Minipro Thermal Cycler (Model: SWT-MIP-0.2-2, Singapore) using the following

169 program: Denaturation for 5 minutes at $95^{\circ} \mathrm{C}$, followed by 40 cycles of 40 seconds of

170 denaturation at the same temperature, annealing for 60 seconds at $65^{\circ} \mathrm{C}$ and elongation at $72^{\circ} \mathrm{C}$

171 for the first 2 minutes and followed by a final extension for 10 minutes. The sequence generated

172 from the automated sequencing of PCR amplified 16S ribosomal RNA was analyzed through

173 NCBI BLAST (http://www.ncbi.nlm.nih.gov) program to ascertain the possibility of a similar

174 organism through alignment of homologous sequences and the required corresponding sequences

175 that were downloaded. The evolutionary history was inferred using the Neighbor-joining method

176 which was performed on the Phylogeny.fr platform through online based software: Muscle (v3.7),

177 Gblocks (v0.91b), PhyML program (v3.0 aLRT) and TreeDyn (v198.3) (Dereeper et al. 2010;

178 Edgar 2004).

2.6. Environmental parameters optimization

182 Optimization of various environmental parameters $(\mathrm{pH}$, temperature, initial dye concentration 183 and inoculum size) for decolorization of Crystal Violet dye were done with some modifications 184 of Shah et al. and 2013 Prasad et al. The mixture was inoculated with the 24 hours incubated 185 bacterial culture and uninoculated crystal violet dye solutions were kept as control. Each 186 experiment was performed in triplicate and the mean values were recorded. To detect the effect of 187 initial dye concentration, media of different dye concentrations $50 \mathrm{mg} / 1$ to $200 \mathrm{mg} / 1$ were used 
188 while 8, 9 and $10 \%(\mathrm{v} / \mathrm{v})$ of 24 hours incubated inoculums were inoculated for dye 189 decolorization.

190.

191 2.7. Assay of dye degradation/decolorization

192 The rate of decolorization expressed as a percentage was determined by observing the reduction 193 of absorbance at absorption maxima $(\lambda \max )$. The uninoculated MS medium supplemented with 194 respective dye was used as a reference. $2 \mathrm{ml}$ of reaction mixture was kept at different time 195 intervals, and the samples were centrifuged at $10,000 \mathrm{rpm}$ for $10 \mathrm{~min}$ to separate biomass. The 196 concentration of dye was determined by absorbance at $660 \mathrm{~nm}$. The measurement of absorbance 197 was done by the Photo-electric colorimeter (AE-11M, China). The color removal efficiency was 198 stated as the percentage ratio based on the following equation (Chen et al. 2003):

Dye Degradation $(\%)=\frac{\text { Initial OD }- \text { Final OD }}{\text { Initial OD }} \times 100$

3. Results and discussion

202 3.1. Physical characterization of textile effluent

203 The observation of physical characters of the collected textile effluent samples had revealed a 204 high load of pollution indicators. The effluent colors of 3 samples were black due to a mixture of 205 different chemicals and dyes and the rest was turquoise blue due to the fact that only turquoise 206 dye was used in the dyeing process. The $\mathrm{pH}$ of the tested samples was slightly acidic to neutral. 207 Temperature of the collected sample were around $18^{\circ} \mathrm{C}$ due to winter season. Physical characters 208 of textile effluent may vary due to the mixing of different types of organic and inorganic 209 compounds derived from different environmental conditions. Chikkara and Rana had observed

210 the colour and smell of textile effluent sample which was black and pungent respectively at $\mathrm{pH}$ 2119.4 (Chhikara \& Rana 2013) whereas Verma and Sarma tested textile waste-water which was 212 brownish-black in color with unpleasant odor at pH 8.3 (Varma \& Sharma 2011). 
215 3.2. Isolation, screening and identification of dye degrading bacteria

216 On the basis of the decolorizing capacity and colony characters 3 isolates were selected from

217 sludge-2 and the isolates were named as CV-S1, CV-S2 and CV-S3 after 72 hours of incubation

218 CV-S1 yielded up to 81.25\% Crystal Violet dye degradation while the rest two CV-S2 and CV-S3, 219 exhibited up to $64.58 \%$ and $25 \%$ dye degradation respectively (Table 1). Thus CV-S1 isolate was 220 selected for identification.

221

222 Table 1: Screening of the best dye decolorizing isolates based on degradation rate

224 The best sequenced portion of $580 \mathrm{bp}$ of $16 \mathrm{~S}$ rDNA of amplified $1500 \mathrm{bp}$ exhibited the highest 225 identity (99\%) with Enterobacter sp. HSL69 according to isolation source. The downloaded 226 corresponding aligned sequences, shown in Table 2, revealed that the phylogenetic relationship 227 between the isolated bacterial strains with other related bacterial strains. During phylogenetic tree 228 construction, strain $\mathrm{CV}-\mathrm{S} 1$ had formed a new branch and the homology indicated that the strain $229 \mathrm{CV}-\mathrm{S} 1$ is under the genus Enterobacter. Therefore, the isolate was identified and named as 230 Enterobacter sp. CV-S1. The newly formed branch confirms that the identified Enterobacter sp. $231 \mathrm{CV}-\mathrm{S} 1$ is a novel species of Enterobacter genus (Figure 1). Numerous potential dye decolorizing 232 bacteria have been reported by scientists from the textile dye effluents, contaminated soil with 233 dyes, dying waste disposal sites, and wastewater treatment plant (Khadijah et al. 2009; Pokharia 234 \& Ahluwalia 2013).

Table 2. Similarity between the isolated bacterial strains $\mathrm{CV}-\mathrm{S} 1$ with other related bacteria found in the GenBank database.

240 Figure 1. Phylogenetic tree analysis: The evolutionary history was inferred using the Neighbor241 Joining method. Highlighted bacterial strains are the isolated bacteria. The phylogenetic tree was

242 reconstructed using the maximum likelihood method implemented in the PhyML program (v3.0 243 aLRT) (Dereeper et al., 2010; Edgar, 2004). 
245 3.3. Growth characteristics

246 The maximum growth of CV-S1was observed at temperature $35^{\circ} \mathrm{C}$ and $\mathrm{pH} 6.50$ while the 247 growth started decreasing within 60-72 hours of incubation (Table 3). Bacterial growth is a 248 complex process associated with various anabolic and catabolic reactions. Eventually, these 249 biosynthetic reactions result in cell division (Raina MM 2009). As the growth-rate hypothesis 250 (GRH) predicts positive correlations among RNA content, phosphorus (P) content and biomass, 251 such relationships have been used to assume patterns of microbial activity, resource availability, 252 and nutrient recycling in ecosystems (Franklin et al. 2011). Hence, the degradation study required 253 considerable of 72 hours of cultivation time.

255 Table 3: Absorption spectra of Crystal Violet at different time intervals 256

3.4. Influence of environmental parameters on crystal violet dye degradation

258 The results of degradation experiment of crystal violet dye by Enterobacter sp. CV-S1 was 259 involved with the effect of $\mathrm{pH}$, temperature, initial dye concentration and inoculum size under 260 aerobic shaking condition at $120 \mathrm{rpm}$.

261

262 3.4.1. Effect of $\mathrm{pH}$ on dye degradation

263 This experiment revealed that the percentage of Crystal Violet dye degradation had improved 264 with the change of $\mathrm{pH}$ in the medium. The higher degradation was observed at $\mathrm{pH} 6.50$ to 7.00 265 while the highest decolorization rate (100\%) was observed at $\mathrm{pH} 6.50$ and lowest $(12.5 \%)$ was at $266 \mathrm{pH}$ 6.00. However, organism showed very low decolorization above pH 7.50 (Figure-2). 267 According to the growth curve study, it was observed that the growth rate of the bacteria was 268 higher at pH 6.5 which probably played a vital role for higher degradation at this $\mathrm{pH}$ level. These 269 observations indicated that the organism could treat efficiently neutral to weakly acidic dyeing 270 waste. Several researches had proved that, the biosorption processes using microbes were highly

$271 \mathrm{pH}$ dependent (Aksu \& Tezer 2005; Kumar et al. 2006). In another research done by Wang et al. 272 (2009) Citrobacter sp. CK3 had achieved the best decolorization of reactive red $180(96 \%)$ at $\mathrm{pH}$ $2736.0-7.0$. In case of red azo dye decoloration by Aspergillus niger, it was observed that the 274 removal percent increased with the rise of $\mathrm{pH}$ and the maximum removal efficiency was reached 
$275(99.69 \%)$ at $\mathrm{pH} 9.0$. Thereafter, whenever the $\mathrm{pH}$ value increases, the decolorization process 276 appeared to decrease (Mahmoud et al. 2017).

278 Figure 2: The effect of $\mathrm{pH}$ on crystal violet dye degradation by Enterobacter $\mathrm{sp}$. CV-S1

\subsubsection{Effect of temperature on dye degradation}

281 The maximum (100\%) degradation was observed at temperature $35^{\circ} \mathrm{C}$ while at temperature $30^{\circ} \mathrm{C}$ 282 and $40^{\circ} \mathrm{C}$, the much adverse effect on the degradation was found and it was $37.5 \%$ in both cases 283 (Figure-3). This might have occurred due to an adverse effect of lower and higher temperature 284 other than $35^{\circ} \mathrm{C}$ on the enzymatic activities and the rate of chemical reaction directly related to 285 temperature change. In addition, Bacteria need optimum temperature for growth. Since dye 286 decolorization is a metabolic process, the change in temperature causes change from optimum results into a decline dye decolorization. The higher temperature causes thermal inactivation of proteins and probably affects cell structures such as the membrane (Shah 2013). Similar effect of temperature was observed by Bacillus subtilis in crystal violet dye degradation (Kochher \& Kumar 2011). Holey (2015) reported that bacterial consortium showed 98\% decolorization at 100 $\mathrm{mg} / \mathrm{L}$ concentration of Congo Red dye at temperature $37^{\circ} \mathrm{C}$. Lalnunhlimi and Krishnaswamy (2016) reported that the microbial community exhibits the optimal degradation efficiency with a temperature ranges from 30 to $35^{\circ} \mathrm{C}$. Wanyonyi et al., observed the optimal temperature for decolorization of Malachite Green by using novel enzyme from Bacillus cereus strain KM201428 at $40^{\circ} \mathrm{C}$ (Wanyonyi et al. 2017).

Figure 3. The effect of temperature on crystal violet dye degradation by Enterobacter sp. CV-S1

3.4.3. Effect of initial dye concentration on dye degradation

300 It was observed that Enterobacter sp. CV-S1 can degrade $150 \mathrm{mg} / 1$ Crystal Violet dye within 72 301 hours. However in higher concentration, dye degradation rate was reduced remarkably (Figure4). This may be due to the decreasing of nucleic acids content ratio, i.e., RNA/DNA, which results to lowering the protein synthesis that inhibits cell division. The decolorization of 500mg/l crystal violet using Bacillus sp. was complete upon continued incubation for $2.5 \mathrm{~h}$ in mineral salt medium amended with glucose and yeast extract but it decreased to less than with increasing the 
306 initial concentration of crystal violet to 600, 700, 800, 900 and $1000 \mathrm{mg} / \mathrm{l}$ (Ayed et al. 2009). The

307 effect of dye concentration on growth plays an important role in the choice of microbes to be

308 used in the bioremediation of dye wastewater, for instance high concentrations can reduce the 309 degradation efficiency due to the toxic effect of the dyes (Khehra et al. 2006). Furthermore, initial

310 dye concentration provides an essential driving force to overcome all mass transfer resistance of

311 the dye between the solid and aqueous phases (Parshetti et al. 2006). Present result indicate that

312 Enterobacter sp. CV-S1 is quite tolerant to Crystal Violet and can decolorize and degrade 313 relatively higher concentration of the dye.

Figure 4. Degradation of different concentration of crystal violet dye by Enterobacter sp. CV-S1

318 3.4.4. Effect of initial inoculums size on dye degradation

319 It was observed that the dye removal capacity had affected by the inoculums size used. The 320 degradation rate had decreased with the declining of inoculum sizes. The most significant result $321(100 \%)$, was obtained when 10\% inoculum was used. The absorption spectra of crystal violet at 322 different time intervals were shown in Table 3 and Figure 5. After 72 hours of inoculation the 323 solution was streaked on a nutrient agar plate and the growth of bacteria was observed after 324 overnight incubation. It proved that the dye degradation was absolutely due to bacteria. After 325 optimizing the environmental parameters, $100 \%$ degradation of $150 \mathrm{mg} / 1$ Crystal Violet was 326 observed within 72 hours at $35^{\circ} \mathrm{C}$ and $\mathrm{pH} 6.50$ under aerobic shaking condition by $10 \%(\mathrm{v} / \mathrm{v})$ 327 Enterobacter sp. CV-S1 without supplying extra carbon and nitrogen source as shown in Figure 328 6. A similar pattern was observed and reported by Ayed et al. (2009) that the dye removal 329 capacity had increased significantly with the escalation in inoculum size. They isolated Bacillus $330 \mathrm{sp}$. which was able to decolorize $500 \mathrm{ppm}$ crystal violet within $2.5 \mathrm{~h}$ under shaking condition at 331 temperature $30^{\circ} \mathrm{C}$ and $\mathrm{pH}$ 7. In another study, the Brilliant Green dye $(10 \mathrm{mg} / \mathrm{l})$ removal by the 332 Klebsiella strain Bz4 in static conditions was observed $81.14 \%$ after 24 hours of incubation and $333100 \%$ dye removal was observed after 96 hours of incubation (Zabłocka-Godlewska et al. 2015). 
335 Figure 5. Degradation rate of Crystal Violet by Enterobacter sp. CV-S1 after optimizing the 336 environmental parameters at different time intervals

337

338

339

340

341

342

343

344

345

346

347

348

349

350

351

352

353

354

355

356

357

358

359

360

361

362

363

364

365

366

Figure 6. 10\% (v/v) of Enterobacter sp. CV-S1 showed $150 \mathrm{mg} / \mathrm{l}$ Crystal violet dye degradation at $\mathrm{pH} 6.50$ and temperature $35^{\circ} \mathrm{C}$ under shaking condition at different time intervals. A, 0 hour; B, 24 hours; C, 48 hours and D, 72 hours (c, control; R1, R2 and R3, replication 1, 2 and 3 respectively).

\section{Conclusion}

In this study, the newly isolated bacteria Enterobacter sp. CV-S1 had demonstrated potentiality for its Crystal Violet dye degradation. The optimum decolorizing parameters of the study were concentration of dye $(150 \mathrm{mg} / \mathrm{l})$, inoculums size $(10 \% \mathrm{v} / \mathrm{v})$ temperature $\left(35^{\circ} \mathrm{C}\right), \mathrm{pH}(6.50)$, with a rotation of $120 \mathrm{rpm}$. It can be concluded from the overall findings that the isolated bacteria Enterobacter sp. CV-S1 could effectively be used as an alternative to the physical and chemical process of textile effluents as they are able to decolorize or degrade highly potential Crystal Violet dye.

\section{Acknowledgement}

We are especially grateful to the Centre for Advanced Research in Science (CARS), University of Dhaka, Bangladesh.

\section{References}

Abadulla E, Tzanov T, Costa S, Robra K-H, Cavaco-Paulo A, and Gübitz GM. 2000. Decolorization and detoxification of textile dyes with a laccase from Trametes hirsuta. Applied and environmental microbiology 66:3357-3362.

Aksu Z, and Tezer S. 2005. Biosorption of reactive dyes on the green alga Chlorella vulgaris. Process Biochemistry 40:1347-1361.

Asad S, Amoozegar M, Pourbabaee AA, Sarbolouki M, and Dastgheib S. 2007. Decolorization of textile azo dyes by newly isolated halophilic and halotolerant bacteria. Bioresource technology 98:2082-2088. 
367

368

369

370

371

372

373

374

375

376

377

378

379

380

381

382

383

384

385

386

387

388

389

390

391

392

393

394

395

396

397

398

399

400

401

402

403

404

405

406

407

408

409

410

411

412

413

414

415

Ayed L, Chaieb K, Cheref A, and Bakhrouf A. 2009. Biodegradation of triphenylmethane dye Malachite Green by Sphingomonas paucimobilis. World Journal of Microbiology and Biotechnology 25:705.

Bhattacharya S, Gupta AB, Gupta A, and Pandey A. 2018. Introduction to Water Remediation: Importance and Methods. Water Remediation: Springer, 3-8.

Chen K-C, Wu J-Y, Liou D-J, and Hwang S-CJ. 2003. Decolorization of the textile dyes by newly isolated bacterial strains. Journal of Biotechnology 101:57-68.

Chhikara S, and Rana L. 2013. Physico-chemical Characterization of Textile Mill Effluent: A Case Study of Haryana, India. Environ We Int J Sci Tech 8:19-23.

Dereeper A, Audic S, Claverie J-M, and Blanc G. 2010. BLAST-EXPLORER helps you building datasets for phylogenetic analysis. BMC evolutionary biology 10:8.

Edgar RC. 2004. MUSCLE: multiple sequence alignment with high accuracy and high throughput. Nucleic acids research 32:1792-1797.

Franklin O, Hall EK, Kaiser C, Battin TJ, and Richter A. 2011. Optimization of biomass composition explains microbial growth-stoichiometry relationships. The American Naturalist 177:E29-E42.

Fulekar M, Wadgaonkar SL, and Singh A. 2013. Decolourization of dye compounds by selected bacterial strains isolated from dyestuff industrial area. Int $J$ Adv Res Technol 2:182-192.

Holey BA 2015. Decolourization of Congo Red dye by bacteria and consortium isolated from dye contaminated soil. Int. Res. J. Sci. 3: 107-112.

Jana H, Roy K, and Mondal K. 2015. Isolation and characterization of dye degrading bacteria from textile industrial waste, Panskura, West Bengal, India. Indian journal of applied research 5:19-23.

Kalyani D, Telke A, Dhanve R, and Jadhav J. 2009. Ecofriendly biodegradation and detoxification of Reactive Red 2 textile dye by newly isolated Pseudomonas sp. SUK1. Journal of Hazardous Materials 163:735-742.

Kaur A, Vats S, Rekhi S, Bhardwaj A, Goel J, Tanwar RS, and Gaur KK. 2010. Physico-chemical analysis of the industrial effluents and their impact on the soil microflora. Procedia Environmental Sciences 2:595-599.

Khadijah O, Lee K, and Mohd Faiz FA. 2009. Isolation, screening and development of local bacterial consortia with azo dyes decolourising capability. Malaysian Journal of Microbiology 5:25-32.

Khehra MS, Saini HS, Sharma DK, Chadha BS, and Chimni SS. 2006. Biodegradation of azo dye CI Acid Red 88 by an anoxic-aerobic sequential bioreactor. Dyes and Pigments 70:1-7.

Kochher S, and Kumar J. 2011. Microbial decolourization of crystal violet by Bacillus subtilis. Biological Forum-An International Journal. p 82-86.

Kumar KV, Ramamurthi V, and Sivanesan S. 2006. Biosorption of malachite green, a cationic dye onto Pithophora sp., a fresh water algae. Dyes and Pigments 69:102-107.

Lalnunhlimi S, and Krishnaswamy V. 2016. Decolorization of azo dyes (Direct Blue 151 and Direct Red 31) by moderately alkaliphilic bacterial consortium. brazilian journal of microbiology 47:39-46.

Mahmoud MS, Mostafa MK, Mohamed SA, Sobhy NA, and Nasr M. 2017. Bioremediation of red azo dye from aqueous solutions by Aspergillus niger strain isolated from textile wastewater. Journal of Environmental Chemical Engineering 5:547-554.

Mittal A, Kurup L, and Gupta VK. 2005. Use of waste materials - bottom ash and de-oiled soya, as potential adsorbents for the removal of amaranth from aqueous solutions. Journal of Hazardous Materials 117:171-178.

Mojsov KD, Andronikov D, Janevski A, Kuzelov A, and Gaber S. 2016. The application of enzymes for the removal of dyes from textile effluents. Advanced Technologies 5:81-86. 
416

417

418

419

420

421

422

423

424

425

426

427

428

429

430

431

432

433

434

435

436

437

438

439

440

441

442

443

444

445

446

447

448

449

450

451

452

453

454

455

456

457

458

459

460

461

462
Mondal P, Baksi S, and Bose D. 2017. Study of environmental issues in textile industries and recent wastewater treatment technology. World Scientific News 61:98-109.

Morales-Álvarez ED, Rivera-Hoyos CM, Poveda-Cuevas SA, Reyes-Guzmán EA, PedrozaRodríguez AM, Reyes-Montaño EA, and Poutou-Piñales RA. 2017. Malachite Green and Crystal Violet Decolorization by Ganoderma lucidum and Pleurotus ostreatus Supernatant and by rGILCC1 and rPOXA 1B Concentrates: Molecular Docking Analysis. Applied biochemistry and biotechnology:1-12.

Mudhoo A, and Beekaroo D. 2011. Adsorption of Reactive Red 158 Dye by Chemically Treated Cocos Nucifera L. Shell Powder. Adsorption of Reactive Red 158 Dye by Chemically Treated Cocos Nucifera L Shell Powder: Springer, 1-65.

Muhd Julkapli N, Bagheri S, and Bee Abd Hamid S. 2014. Recent advances in heterogeneous photocatalytic decolorization of synthetic dyes. The Scientific World Journal 2014.

Muhd Julkapli N, Bagheri S, and Bee Abd Hamid S. 2014. Recent advances in heterogeneous photocatalytic decolorization of synthetic dyes. The Scientific World Journal 2014.

Olukanni O, Osuntoki A, and Gbenle G. 2006. Textile effluent biodegradation potentials of textile effluent-adapted and non-adapted bacteria. African Journal of Biotechnology 5.

Parshetti G, Kalme S, Saratale G, and Govindwar S. 2006. Biodegradation of Malachite Green by Kocuria rosea MTCC 1532. Acta Chimica Slovenica 53.

Pokharia A, and Ahluwalia SS. 2013. Isolation and screening of dye decolorizing bacterial isolates from contaminated sites. Textiles and Light Industrial Science and Technology.

Raina MM IL, Charles PG. 2009. Risks from pathogen in biosolids. California: Elsevier Inc.

Rajamohan N, and Rajasimman M. 2012. Kinetic modeling of dye effluent biodegradation by Pseudomonas stutzeri. Engineering, Technology \& Applied Science Research 3:387-390.

Rawat D, Mishra V, and Sharma RS. 2016. Detoxification of azo dyes in the context of environmental processes. Chemosphere 155:591-605.

Shah MP. 2013. Microbial degradation of textile dye (Remazol Black B) by Bacillus spp. ETL2012. Journal of Applied \& Environmental Microbiology 1:6-11.

Sharma S, Sharma S, Singh P, Swami R, and Sharma K. 2009. Exploring fish bioassay of textile dye wastewaters and their selected constituents in terms of mortality and erythrocyte disorders. Bulletin of environmental contamination and toxicology 83:29-34.

Sriram N, Reetha D, and Saranraj P. 2013. Biological degradation of Reactive dyes by using bacteria isolated from dye effluent contaminated soil. Middle-East Journal of Scientific Research 17:1695-1700.

Subhathra M, Prabakaran V, Kuberan T, and Balamurugan I. 2013. Biodegradation of Azo dye from textile effluent by Lysini bacillus sphaericus. Sky Journal of Soil Science and Environmental Management 2:1-11.

Varma L, and Sharma J. 2011. Analysis of physical and chemical parameters of textile waste water. Journal of International Academy of Physical Sciences 15.

Verma AK, Dash RR, and Bhunia P. 2012. A review on chemical coagulation/flocculation technologies for removal of colour from textile wastewaters. Journal of environmental management 93:154-168.

Wang H, Su JQ, Zheng XW, Tian Y, Xiong XJ, and Zheng TL. 2009. Bacterial decolorization and degradation of the reactive dye Reactive Red 180 by Citrobacter sp. CK3. International Biodeterioration \& Biodegradation 63:395-399.

Wanyonyi WC, Onyari JM, Shiundu PM, and Mulaa FJ. 2017. Biodegradation and Detoxification of Malachite Green Dye Using Novel Enzymes from Bacillus cereus Strain KM201428: Kinetic and Metabolite Analysis. Energy Procedia 119:38-51. 
463 Winnepenninckx B, Backeljau T, and Dewachter R. 1993. Extraction of high molecular weight 464 DNA from molluscs. Trends in Genetics 9:407.

465 Zabłocka-Godlewska E, Przystaś W, and Grabińska-Sota E. 2015. Dye decolourisation using two $466 \quad$ Klebsiella strains. Water, Air, \& Soil Pollution 226:2249.

467 Zollinger H. 2003. Color chemistry: syntheses, properties, and applications of organic dyes and 468 pigments: John Wiley \& Sons. 


\section{Table $\mathbf{1}$ (on next page)}

Screening of the best dye decolorizing isolates based on degradation rate 
1

\begin{tabular}{|c|c|c|c|c|c|}
\hline Isolates & Initial OD & Final OD & $\begin{array}{l}\text { Degradation } \\
\text { rate }(\%)\end{array}$ & $\begin{array}{c}\text { Average degradation } \\
\text { rate }(\%)\end{array}$ & $\begin{array}{l}\text { Duration of } \\
\text { observation }\end{array}$ \\
\hline \multirow{3}{*}{$\mathrm{CV}-\mathrm{S} 1$} & 0.08 & 0.015 & 81.25 & \multirow{3}{*}{81.25} & \multirow{3}{*}{72 hours } \\
\hline & 0.08 & 0.015 & 81.25 & & \\
\hline & 0.08 & 0.015 & 81.25 & & \\
\hline \multirow{3}{*}{$\mathrm{CV}-\mathrm{S} 2$} & 0.08 & 0.03 & 62.50 & \multirow{3}{*}{64.58} & \multirow{3}{*}{72 hours } \\
\hline & 0.08 & 0.03 & 62.50 & & \\
\hline & 0.08 & 0.025 & 68.75 & & \\
\hline \multirow{3}{*}{$\mathrm{CV}-\mathrm{S} 3$} & 0.08 & 0.06 & 25.00 & \multirow{3}{*}{25.00} & \multirow{3}{*}{72 hours } \\
\hline & 0.08 & 0.06 & 25.00 & & \\
\hline & 0.08 & 0.06 & 25.00 & & \\
\hline
\end{tabular}




\section{Table 2 (on next page)}

Similarity between the isolated bacterial strain $\mathrm{CV}-\mathrm{S} 1$ and other related bacteria found in the GenBank database. 
1

2

\begin{tabular}{clcc}
\hline Isolated strain & \multicolumn{1}{c}{ Closed bacteria } & Accession no. & Identity (\%) \\
& & & \\
\hline \multirow{6}{*}{ CV-S1 } & Enterobacter cloacae RU14 & KJ607595.1 & 99 \\
& Enterobacter cloacae RJ04 & KC990807.1 & 99 \\
& Enterobacter cloacaeBM8 BM & JX514423.1 & 99 \\
& Enterobacter sacchari SP1 & HM461195.1 & 99 \\
\hline
\end{tabular}

3 


\section{Table 3 (on next page)}

Absorption spectra of Crystal Violet at different time intervals 
1

\begin{tabular}{|c|c|c|c|c|c|c|c|c|c|c|}
\hline \multirow{2}{*}{$\begin{array}{l}\text { Conc. of } \\
\text { CV dye }\end{array}$} & \multirow[t]{2}{*}{ Measurements } & \multicolumn{9}{|c|}{ Elapsed Time (in hours) } \\
\hline & & $\mathbf{0}$ & 2 & 12 & 24 & 30 & 36 & 48 & 60 & 72 \\
\hline $150 \mathrm{mg} / \mathrm{L}$ & OD & 0.12 & 0.12 & 0.11 & 0.08 & 0.06 & 0.04 & 0.02 & 0.01 & 0 \\
\hline & $\begin{array}{l}\text { Degradation } \\
\text { rate }(\%)\end{array}$ & 0 & 0 & 8.33 & 33.33 & 50.00 & 66.67 & 83.33 & 91.67 & 100 \\
\hline
\end{tabular}

2 


\section{Figure 1}

Highlighted bacterial strains are the isolated bacteria. The phylogenetic tree was reconstructed using the maximum likelihood method implemented in the PhyML program (v3.0 aLRT) (Dereeper et al., 2010; Edgar, 2004).

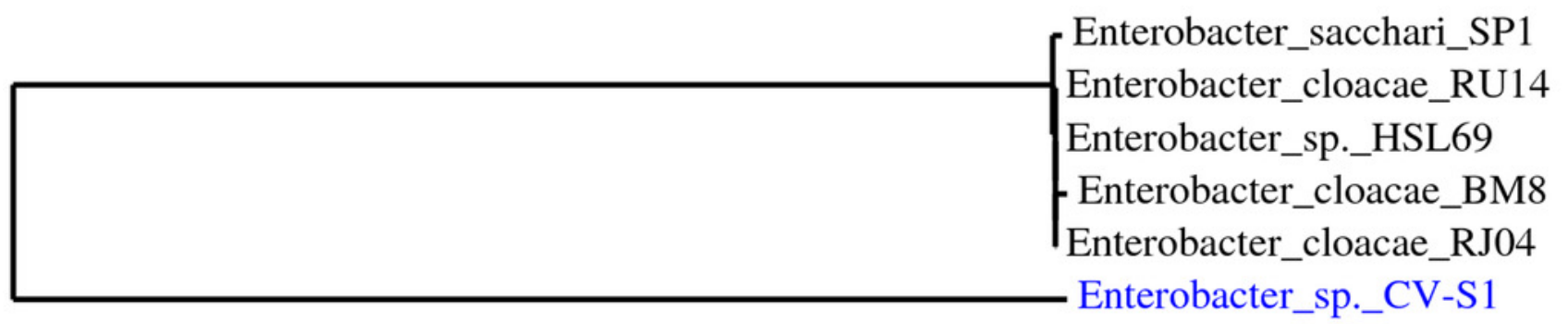

0.2 
Figure 2

The effect of $\mathrm{pH}$ on crystal violet dye degradation by Enterobacter sp. CV-S1

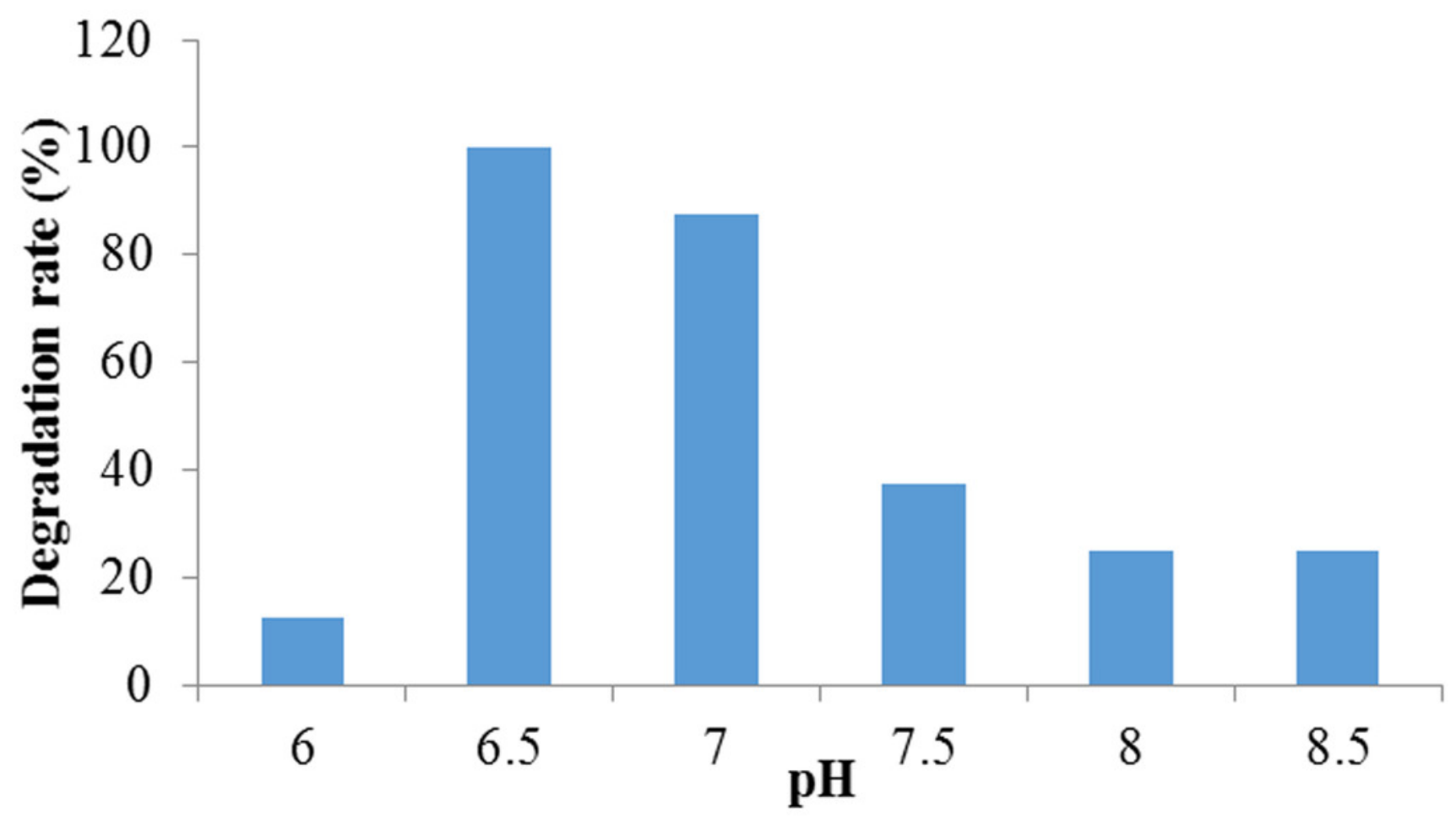


Figure 3

The effect of temperature on crystal violet dye degradation by Enterobacter sp. CV-S1

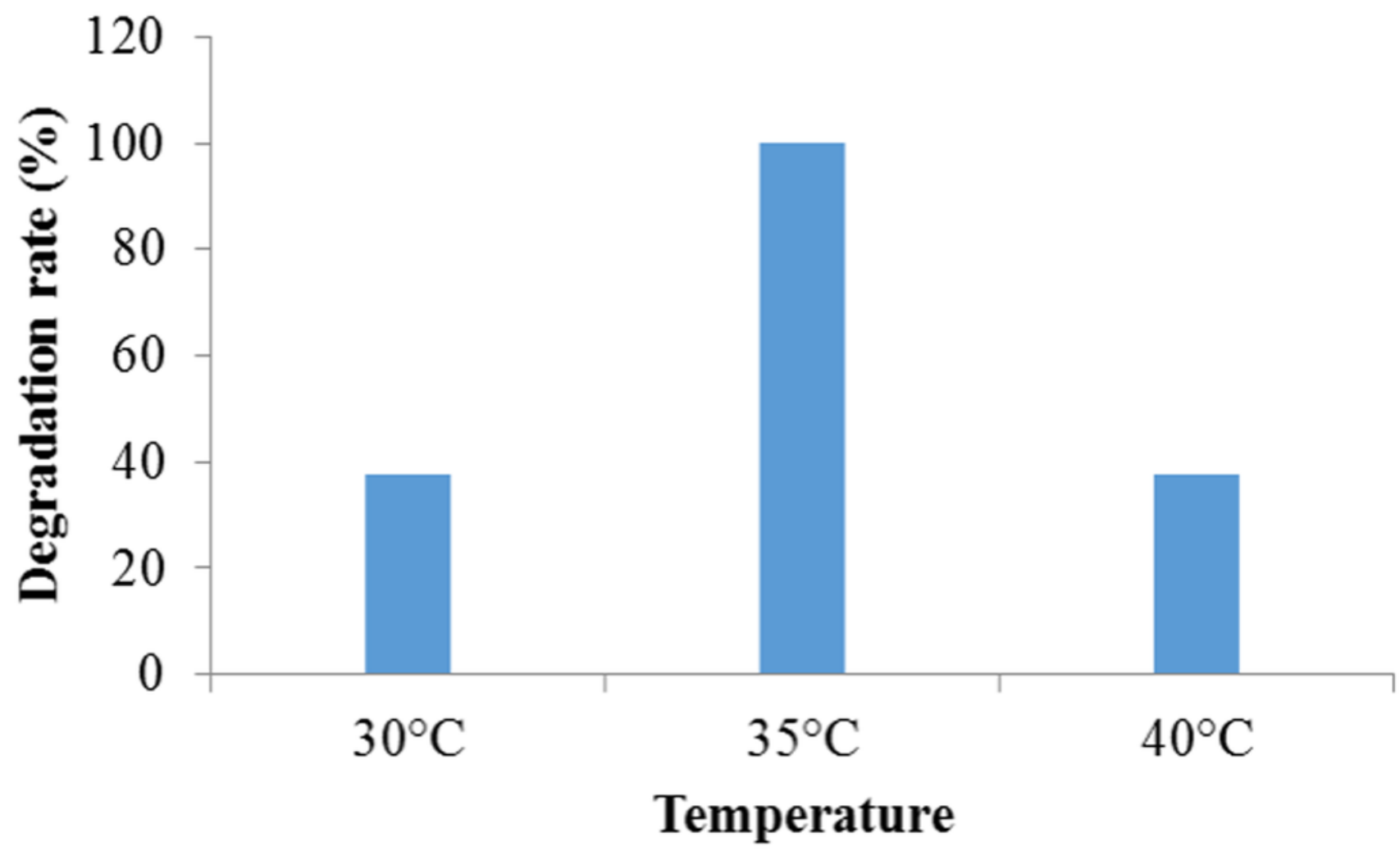


Figure 4

Degradation of different concentration of crystal violet dye by Enterobacter sp. CV-S1

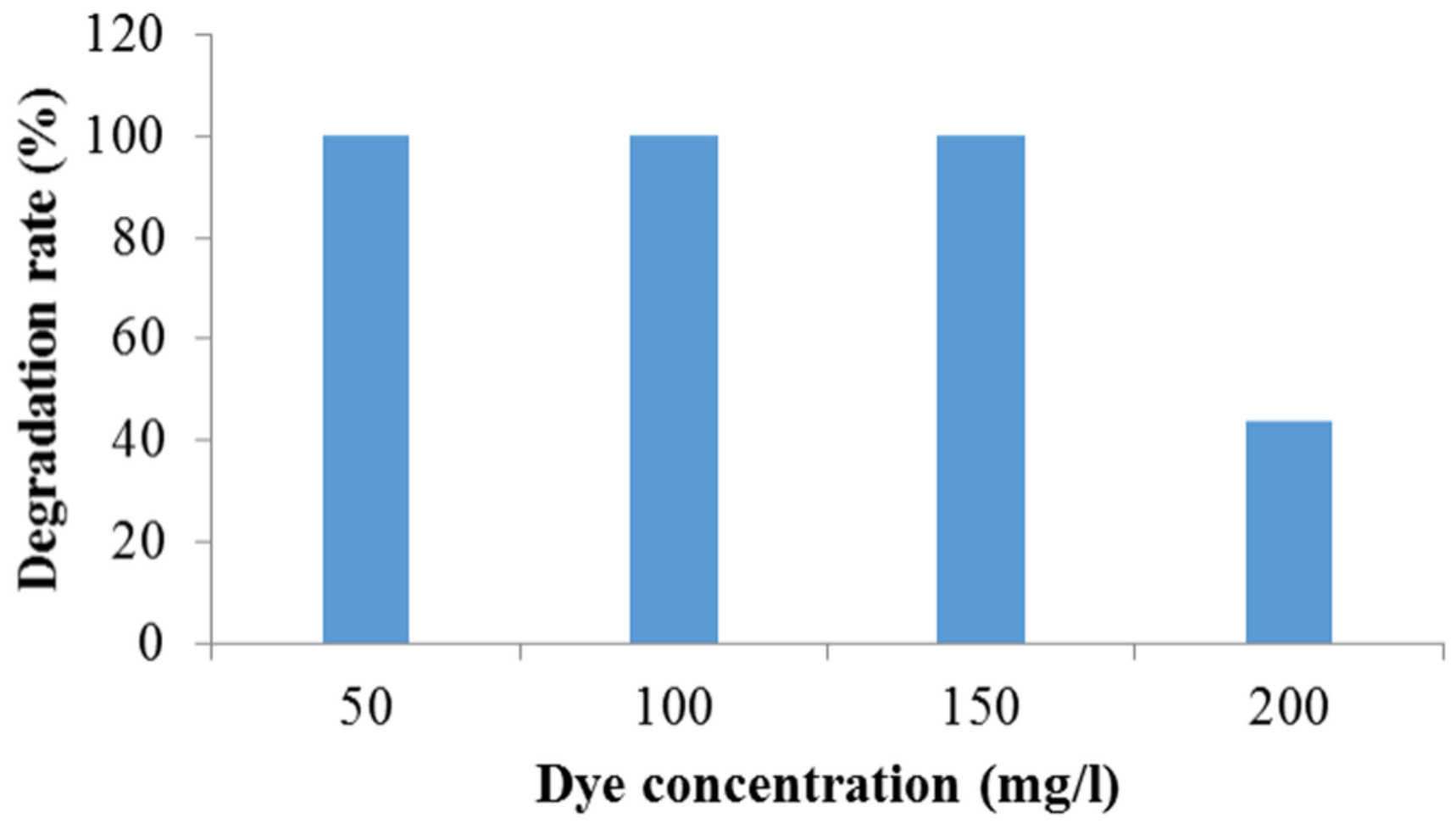


Figure 5

Degradation rate of Crystal Violet by Enterobacter sp. CV-S1 after optimizing the environmental parameters at different time intervals

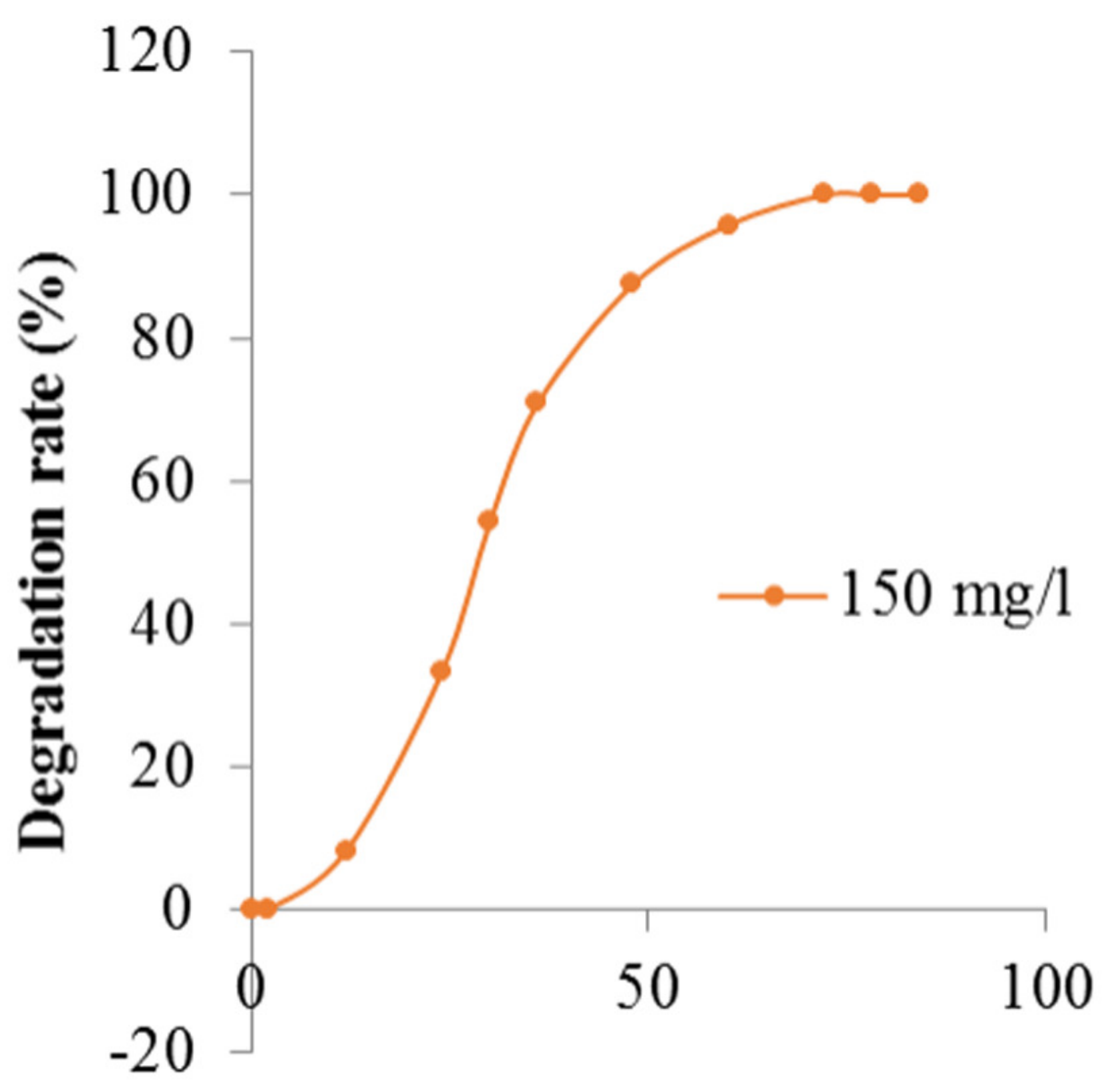

Elapsed time (hours) 


\section{Figure 6}

10\% (v/v) of Enterobacter sp. CV-S1 showed $150 \mathrm{mg} / \mathrm{l}$ Crystal violet dye degradation at $\mathrm{pH} 6.50$ and temperature $35^{\circ} \mathrm{C}$ under shaking condition at different time intervals. $\mathrm{A}, 0$ hour; B, 24 hours; C, 48 hours and D, 72 hours (c, control; R1, R2 and R3, r
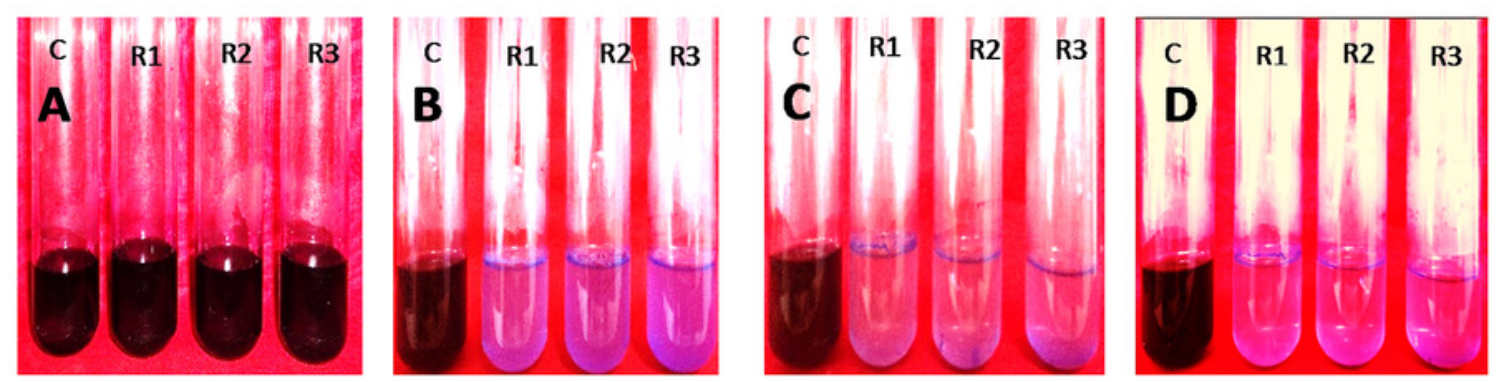